\title{
Experimental verification of the frequency spectrum of unwears and wears guidance tube on the technological head vibrations creation in the production system with AWJ technology
}

Stanislav Fabian, Štefánia Salokyová, Patrik Jacko

Institute of Faculty of Manufacturing Technologies, The Technical University of Košice, Bayerova 1, 08001 Prešov, Slovak Republic.stanislav.fabian@tuke.sk,stefania.salokyova@tuke.sk, patrik.jacko@tuke.sk.

The solution and evaluation of the production system (PS) operation with water jet technology was addressed in more works. It is appropriate to complement this knowledge from works focused on investigation of the other factors effect which affecting the emergence and spread of technological head vibrations, affecting reliability, durability, economic efficiency and operation safe of PS with water jet technology. The article presents experimental investigation results of the vibration acceleration frequency spectrums during cutting steel by unwear and wear rectifying tube with water jet technology. The vibrations size was assessed by two basic vibrations parameters - vibrations frequency and vibration acceleration amplitude.

Keywords: hydroabrasive water jet, technological head, vibration acceleration amplitude, frequency, cutting of material

\section{Acknowledgement}

The paper presents partial results of scientific project VEGA 1/0544/08 and results of Institutional research task IU 5/2011.

\section{References}

[1] FABIAN, S., KRENICKÝ T. (2008). Vibrodiagnostika výrobných systémov s technológiou AWJ. In.: Spravodaj ATD SR, 2008, pp. 26 - 27, ISSN 1337-8252.

[2] FABIAN, S., STRAKA, L. (2008). Prevádzka výrobných systémov, In.: Vydavatel'stvo Michala Vaška. Prešov, Prešov 2008, s. 251, ISBN 978-80-8073-989-8.

[3] FEDÁK, M., FABIAN, S. (2007). An example of theoretical knowledge application in the vibrodiagnostical laboratory, In: Výrobné inžninierstvo, roč.6, no.3, 2007, p.75-78, ISSN 1335-7972.

[4] JACKO, P., KRENICKÝ, T., SALOKYOVÁ, Š., RIMÁR, M. (2011). Zistovanie vibrácií technologickej hlavice v procese rezania vodným prúdom. 2011. In.: Strojárstvo extra.č. 5 (2011), s. 46/1-46/3. - ISSN 1335 2938.

[5] Jacko, P.: Modelovanie a simulácia technologických parametrov v nadväznosti na použitie netradičných druhov abrazíva v technológií AWJ, Dizertačná práca, FVT TU Košice, Prešov 2010.

[6] KREIDL, M., ŠMÍDL, R. (2006). Technická diagnostika - senzory, metódy, analýza signálu. In.: Ben Praha. 2006. s. 406. ISBN 80-7300-158-6.

[7] MULLER M., VALÁŠEK P. (2011). Interaction of steel surface treatment by means of abrasive cloth and adhesive bond strength. In.: Manufactruing Technology. 2011. pp. 49 - 57. ISSN 1213-2489.

[8] SALOKYOVÁ, Š., FABIAN, S. (2011). The influence of abrasive mass flow on vibrations in the water jet cutting process. 2011. In.: Výrobné inžiniersvto. Roč.10, č. 1 (2011), s. 31 - 34. ISSN 1335-7972.

[9] SALOKYOVÁ, Š. (2011). Návrh metód a technických systémov (hardvér a softvér) pre elimináciu vibrácií a hlučnosti s aplikáciou na výrobné systémy s vybranými druhmi technológie. Písomný materiál k dizertačnej práci. 08.04.2011. Prešov. 2011.

[10] ŤAVODOVÁ M. (2011). Evaluation of roughness of the AIMg3 cut surface after abrasive water jet processing. In.: Manufactruing Technology. 2011. pp. 42 - 48. ISSN 1213-2489.

[11] VALÁŠEK Petr, MULLER Miroslav. (2011). Využiti abraziva z procesu dělení metodou AWJ v oblasti materiálového výzkumu. In.: Manufactruing Technology. 2011. pp. 37-42. ISSN 1213-2489. 